\title{
The Use of Stable Expressions in Modern Economic Discourse as an Emotional Increase in the Potential Impact on Purchasing Power
}

Irina Karabulatova, ${ }^{* *}$ Margarita S. Vykhrystyuk, 'Natalia G. Dolzhenko, 'Elena I. Mychko and Elena V. Potmenskayá́

\section{Abstract}

This study is an attempt to analyse economic discourse metaphors and stable expressions. Significant attention is paid to metaphor creative potential in the field of terms formation as well as representation of certain aspects of economic reality events. Some rhetoric models are especially studied from the point of view of their rhetoric impact on the potential audience. The market of goods and services began to develop rapidly in the modern consumer society, and as a result, the corpus of language tools began to expand to attract the attention of potential recipients of goods and services. Economics and linguistics are two spheres of science that are united by humans acting and thinking/ speaking. Modern consumer society requires members of society equipped with economic knowledge that facilitate the process of acquiring something. Today, advertising with economic terminology is becoming more diverse, and it can be targeted at professionals and the broadest segments of the population. Recently, not only linguistic but also paralinguistic levels of advertising discourse realisation have become more and more relevant. The authors consider the phenomenon of linguistic metaphors in economic advertising discourse. The complexity of understanding the material is due to the use of linguistic and cultural stereotypes of the local type. The authors propose to pay attention to the fact of using metaphors of a language culture to attract potential consumers of economic services and create an image of an attractive product of economic discourse in one of the primary mechanisms for managing economic interests in the consumer society. Hence, there is a need to study economic terminology and its functioning in modern economic discourse. This study considers the metaphors of economic discourse as a manifestation of his interdiscursive nature. We analyse the compatibility of economic metaphors with national and cultural symbols and possibilities to influence the audience.

Keywords: Economic Discourse; Term Creative Potential; Stable Expressions; Metaphoric Character; Evaluativity; Rhetoric Impact

\footnotetext{
${ }^{+}$Department of Foreign Languages, Faculty of Philology,

Peoples' Friendship University of Russia, RUDN-university, Moscow, Russia Assistant Professor,

*Corresponding Author, Email: Radogost2000@mail.ru

'Federal State Autonomous Educational Institution of higher professional Education "Tyumen State University", Tyumen, Russia, Email: MVykhrystyuk@ugrasu.ru

'Federal State Budgetary Educational Institution of higher education Yugra State University, Khanty-Mansiysk, Russian Federation, Email: NDolzhenko@ugrasu.ru

${ }^{¥}$ Doctor of Pedagogy, Professor of the Institute of Pedagogy, Immanuel Kant Baltic Federal University, Kalilningrad, Russia, Email: EMychko@kantiana.ru

ÍPhD in Education, Associate professor of the Institute of Pedagogy, Immanuel Kant Baltic Federal University, Kaliningrad, Russia, Email: EPotmenskaya@kantiana.ru

(C) 2020 Karabulatova et al. This is an Open Access article distributed under the terms of the Creative Commons Attribution License (http://creativecommons.org/licenses/by/2.0), which permits unrestricted use, distribution, and reproduction in any medium, provided the original work is properly cited.
} 


\section{Introduction}

Economics is fundamentally different from the exact and natural sciences in that it does not deal with an individual, but with a member of society, exposed to the influence of traditions, national mentality, and political institutions. The country's economy shows the dynamics of the development of society, where the well-known postulate is realised: language does not exist outside society, but society cannot exist without language. There remains an explicit correlation between a country's economic achievements, culture and language.

Stable expressions and metaphors are able not only to evaluate objects and events but also to express a definite opinion and even impose it (Koryakovtseva et al., 2016; Saenko et al., 2015).

Modern economic discourse is heterogeneous. It includes the following components: 1) slang economic discourse as communication within the professional community; 2) professional economic discourse as a practical discourse of economists, accountants, managers, marketers, and others; 3) scientific economic discourse; 4) everyday economic discourse as stereotypes about the economy in society; 5) economic discourse in related Sciences (political science, sociology, history, journalism, and others). Therefore, we propose to consider the economic discourse as an everyday institutional discourse, which provides the result, discussion and preservation of knowledge in such a generalised area like the economy (Lanshakova et al., 2003; Magnitskaya, 2003; Paris, 2004; Richie, 2004; Shiganova et al., 2018; Pismennaya, 2016).

The structural shift in favour of the services sector has led to a redistribution of factors of production across the economy. The fundamental purpose of this study is to explore the use of stable expressions in modern economic discourse as an emotional increase in the potential impact on purchasing power. The study begins with a brief description of materials and methods. This follows a critical analysis of the results.

\section{Materials and Methods}

In order to examine the use of stable expressions in modern economic discourse as an emotional increase in the potential impact on purchasing power, the central object of the research is the identification of various zones and fields of metaphorical space of economic discourse (2014-2019). We have extracted examples illustrating the stable expressions and metaphors of economic discourse from the internet analogues of leading English and Russian periodicals (The Economist, Trading, 2018-2019; Economics, 2015-2018; US News, 2016; The NY Times, 2016; The Guardian, 2016; the Russian newspaper "Kommersant", 20162019; Russian magazine "Expert", 2016-2018; Russian weekly newspaper "Arguments and facts", 2016-2018; Russian magazine "Issues of Economic", 2016-2018. Internet resources include:

- www.mk.ru;

- www.aif.ru;

- www.gazeta.ru;

- www.novayagazeta.ru;

- www.vm.ru;

- www.vedomosti.ru;

- www.nytimes.com;

- www.theguardian.com;

- www.fusionnews.net;

- www.theatlantic.com;

- www.bbc.com/russian;

- www.bbc.com;

- www.telegraph.co.uk;

- www.theweek.com;

- www.reuters.com;

- www.economist.com.

The material was obtained by continuous sampling.

Metaphors of economic discourse have a nuclear-peripheral structure according to zonalfield differentiation. Ethno-cultural values of English economic discourse is reflected in the following themes: 1) the functioning of economic entities of the state (144 publications); 2) relations at the international level (121 publication); 3) consumers (67 publications); 4) domestic economic policy of the state represented by the minimum (21 publication). 
We used complementary methods to solve the problem: theoretical analysis, generalisation of literature on the problem of research, analysis of documents, textbooks on Economics, observation of the features of communication in the professional economic environment, interpretation method, lexical-semantic analysis, contextual analysis, frequency statistical analysis, generalisation, mathematical methods of information processing. The authors of economic mass-media texts use metaphors to convey their ideas to the recipient in a more convenient and accessible form.

Stable expressions, metaphors allowed us to present that cannot be viewed using naked eyes. These expressions are difficult to be described in terms of the language of science; and importantly, challenging to find the exact term. Economic metaphorical terms refer to a specific class of words that conveys abstract meanings. For example, economic terminology has borrowed the concept of "blue chip" from the game of poker to refer to the securities of companies with high reputational and financial capital.

\section{Results}

Information content and emotionality are characteristic features of economic mass-media discourse; they illustrate the unification of the features of both scientific and artistic presentation in it. This feature meets the needs of both scientific and artistic storytelling (Savchuk et al., 2019). The use of metaphors in economic discourse is based on typical ways of presenting the material in a locus and in a chronotope, so we find lexical frequency units and phraseological units.

Anthropocentric models are the most productive models in economic discourse; they transform the matrix of human behaviour following the needs of society (Karabulatova et al., 2017). For this purpose, parts of the economic system are shown as a metaphor for comparison with the organs of the human body. At the same time, the metaphor of the economic cycle is associated with human feelings and ideas. For example, the main economic artery; the heart of the European economy; the awakening of trade unions; the heavy breathing of business; market fatigue; to seduce investors.

The technique of personification often serves as the basis for metaphorisation. Marketing specialists, for example, compare manufactured products and economic cycles with periods of human life: a new generation of products; the life cycle of a product; the process of product revival; the stage of product maturity; death. The concept of evaluation implies two types of attitude to the problem: condemnation and approval in accordance with this study, which is the subject of analysis in this work, can be divided into four groups, including eight types of representation of problems covered in economic journalism, and, accordingly, eight types of metaphorisation in economic journalism.

Economic metaphors make associative connections with inanimate beings (zombies) or imitating living beings (puppets), such comparisons indicate a lack of activity or dependence on someone. Such metaphors are accompanied either by a negative characterisation of the events described or by quasi-legal and illegal operations. So, the Bank metaphorically referred to as a zombie Bank, has a questionable appearance.

A zombie bank is a financial institution that has an economic net worth less than zero but continues to operate because its ability to repay its debts is shored up by implicit or explicit government credit support (Financial Dictionary, 2020). ${ }^{1}$

Morbid metaphors represent a different type of economic metaphor. These metaphors are highly productive. This type of metaphors compares the economic subjects and objects with the condition. This type of economic metaphor compares all the problems of an economic crisis to diseases that need treatment: sick economy; the agony of the Euro; anaemic economy; financial panic is contagious;

\footnotetext{
${ }^{1}$ Retrieved on 20 February 2020 from, https://ru.mfginvest.com/zombie-bank
} 
bloodless economy; moribund economy; paralysed markets.

The negative aspect of this metaphorical model is as follows: 1) the government and the leaders of various ranks are not responsible for the problems; 2) economic problems are a complex and serious disease; 3 ) some imaginary "doctor" is responsible for solving economic problems "diseases"; this mythologised "doctor" should begin treatment and give medicine: to cure the economic crisis; to restore financial health; crisis pill.

The next type of economic metaphor is militaristic. Militaristic, economic metaphors identify business with war: business is a military operation, the economic system is a battlefield, economic agents are warriors/soldiers who can win or lose. Hence, we see such militaristic, economic metaphors as price war; the battle for the Euro; the battle for employment; war for markets. The modern economic world views competition as a struggle, and national currencies and financial capital play the role of weapons, while the functions of the national banking system have parallels with the functions of arms factories.

Another interesting type of economic metaphors includes the sport and the game. This type of economic metaphor is built on the human understanding of wrestling and the game model of opposing teams, winners and losers. This type of economic metaphor is very dynamic and expressive, because economic sports metaphors reflect the most critical moments of economic life in simple and understandable terms, calling for competition and victory. As a result, we have the following metaphoric terms:

handicap - the word is used in sports when a weaker opponent is given a head start in the form of reduced distance, load, and similar other metaphors. Over time, the range of the word meanings widened, and it came to mean not only the competition but the aforementioned preferences, as well as barriers and obstacles.

player - any game participant, and in economic terms - it is any individual, company or government that must choose between different strategies.

dominoes effect - widely used in European languages term for a negative financial impact on the interbank market in the event of default of one or more related banks in terms of loan repayment.

forward - in football and hockey it is the frontline player, striker and the economy so designate a financial transaction on the foreign exchange market, supplying currency at the agreed time at a rate agreed at the time of the transaction. Forward transactions - are urgent cash transactions; forward contract - a contract under which one party agrees on certain terms to transfer the goods, securities or funds to the other; forward market - a market in which transactions are concluded and settled in for a long time.

The next type of economic metaphor is transport models, which conceptualise the economy as a journey, expressing the progress in each direction, to the goal of economic activity. For example, a locomotive is an industry that is or may become the" engine " of economic development; a state that is likely to lead the world economy out of a crisis.

Another type of economic metaphor is associated with the designation of categories of the state. As a rule, this is the state of water. For example, money is represented in this type of metaphor as a liquid. Most metaphors have a reasonably stable dictionary form and refer to common expressions: injection-mass embedding of capital, credit, and other metaphors.; prosperity, inflow-inflow, the appearance of something in large quantities (for example, investments, goods, products, customers); capital outflow-the country's funds sent to other countries in the form of investments, loans; the movement of capitalmovement of capital between the two countries; clean, clean float [ing] the system in which the authorities do not try to influence market demand and supply; dirty float [ing] the manipulation perpetrated by the regulatory authorities over its exchange rate in the floating exchange rate system aimed at obtaining a 
competitive advantage over trading partners; floating exchange rate - loose change, currency fluctuations; Cash flow - the movement of goods and values; the fluctuation of market condition where supply and demand are poorly related.

The next type of economic metaphor is related to flora and fauna. Economic animalistic metaphors make extensive use of tiger and dragon metaphors. Researchers designate tiger economies as countries with aggressive economic growth. Countries whose economies in a short time made the transition from backward, typical of developing countries, to highly developed, were called the four little dragons of Asia (Hong Kong, South Korea, Singapore, Taiwan).

The so-called "market animals" represent the largest and most exotic group of zoometaphors/ Zoological metaphors). Who just cannot be found in the "Financial zoo"? First, there are four types of investors (traders). Investor of a bulltype believes that the market will grow and seeks to buy. The term originated from the fact that the bull, attacking, skewer pray on the horns and throws up. Bear expects recession and market declines. Bears nicknamed so because the animal tramples his victim, pushing it down into the ground. Chickens -a symbol of indecision and cowardice in the English-speaking world. There is an English saying as greedy as a pig, hence the origin of the name pigs for the investors who are not afraid to take risks.

There are specific classification enterprises types in association with animals (see Matrix Scheme of Boston Consulting Group), sorting the company into four groups: stars bring a substantial income, but require significant investment to ensure growth rates; cash cows have a high market share, but low sales growth; problem children have the lowest share of the market, but the high rate of growth; dogs have low growth rates and low market share (Karabulatova, 2013).

Mechanical metaphors can be organised into three sense groups on the basis of the metaphor source: 1) the types of mechanisms: lever, leverage; instrument; mechanism; motor; 2) mechanism condition, the evaluation of which is at the same time the evaluation of the economy state: a good (bad) economic mechanism; 3) processes and operations performed with mechanisms: mounting; demounting; squeeze; slowdown.

Economic construction metaphors are classified according to the basis of source selection into two semantic groups: 1) construction and construction activities: to build, building; supporting construction; 2) house and parts of the house, many metaphoric terms belong to this type: for example, tax niche; low-income poverty threshold; price ceiling .

The weather or nature metaphor is very suitable for concealing the exact causes of the problem situation (metaphor euphemistical function), because, as in the case with morbid metaphors, does not identify the perpetrators of the situation. So, the crisis in terms of extreme weather events is presented as a natural disaster, the causes of which cannot always be explained: tempest, storm; earthquake; financial turbulence; hurricane; tsunami.

Spatial or orientation metaphors, which dominates the vertical upward movement, usually give a positive assessment of the described processes: take-off; starting. Conversely, metaphors, representing the downward motion include a negative assessment of what is happening: slump; bottom. The latter was a crucial metaphor in the description of the heavy financial and economic crisis that broke out in 2008.

Metaphor serves as a tool for the creator of the text of economic topics, through which the creator can subtly regulate the process of perception of economic information.

If the author of an article on economic topics is a politician or a specialist who influences the political sphere of life of the country, then with the help of metaphors can regulate public mood and influence political processes. The economic metaphor allows the recipient to clearly imagine the economic process, especially in times of crisis. An experienced politician manipulates 
economic data using metaphors for the most significant benefit to himself/herself.

Articles on economic topics devoted to the understanding of crisis economic situations in the United States and other countries are mainly presented through conceptual (cognitive) metaphors: ontological, structural and orientation (Lakoff, 2004). Ontological metaphors serve as a way of perceiving events, activities, emotions or ideas as material entities and substances. Structural metaphors represent cases "where one concept is metaphorically structured in terms of another." In the process of metaphorisation of this kind is the identification of various objects or phenomena. Under the orientation, metaphor is understood as a type of metaphor, which is based on spatial oppositions such as "top-bottom", "inside-outside", "front side - backside", "deep - shallow", "centreperiphery".

The identified types of metaphorisation serve as a lexical form of a negative and positive evaluation of the four main problems for this genre, thus constituting eight types of metaphorisation. We consider these types through the lexical characteristics of metaphorical terms.

\section{Discussion}

Values for the English-language economic journalism are such concepts as the construction of relations between economic entities at the international level, the functioning of economic entities of the state, the attitude of economic entities to the consumer, the internal economic policy of States (Wynne, 2001; Kostruba, 2019).

The text has the full attention: some scientists see it as discourse, that is, in the broad context of a certain field (Salter, 2003); other researchers focus on the external structure of the text and the formal ways of ensuring the consistency and integrity of statements, and describe the communicative function of the text (Riazi, 2003); the third group of researchers approach the text in a comprehensive and premised on the assumption that the text is a unity of form and content, it is therefore, necessary to analyse the text taking into account the relationship of these two factors (Sanders and Spooren, 2012).

The next group deals with the study of relations in the text of units of different levels and comes to the concept of text structure. The number of works devoted to the study of the relationship between text and thinking, and the study of human thought processes as the key to understanding the nature of the text, it seems insufficient to argue that this topic has received comprehensive coverage. The statement about the direct connection of thought processes and the semantic nature of the text is one of the main theoretical provisions of this work, so scientists pay attention to the elements of linguistic theories that led to the formation of a functional-pragmatic approach to the text in its modern form (Schmitt, Schröder, and Pfaller, 2018).

The researcher uses the concept of chronotope to explain the internal semantic organisation of the statement and the text. M. M. Bakhtin understands the chronotope as the relationship of temporal and spatial relations artistically assimilated in the literature (Bakhtin, 1975). M. M. Bakhtin (1975) calls language models motives. At the same time, C. Fillmore and $\mathrm{M}$. Minsky (2006) designate them as frames. They define a frame as a system of words and phrases organized around a concept, a fragment of reality (Gavrilova, 2014). Several modern researchers (J. Lakoff, M. Johnson, J. Malrier, and V. Tolochin, E. Lukyanova) studied the text within the cognitive-pragmatic direction, which implies the unity of the process of text creation and mental operations. The fundamental postulate of this theory says: the text is created to solve a particular problem that prevents the satisfaction of a specific need (Luchinskaya et al., 2018).

Systems linguistics - a field created by M.A.K. Halliday-considers it essential to take into account the social context of language communication. The presence of textual functions and choice of appropriate units when creating the text talks about the existence of individual models or types, setting of the text that depends on the text, purpose, author, and 
personality of the recipient (Temirgazina et al., 2019; Gavrilova, 2014; Halliday, 2006).

We distinguish such parameters, according to Z. F. Khachmafova (2017), in the characteristic of economic metaphor terms as 1) model-oriented analysis and 2) nonverbal aspects of descriptive characteristics.

The main parameters of the economical metaphor are as follows:

- the term exists at the level of the image and has a clear structure of allegory;

- the term appeals to the experience of the past;

- the term contains a constant, unchanging assessment that does not change the meaning of the allegory;

- the term provides an adequate understanding of the economic problem/ situation.

Critics of metaphors assign priority to their impact function on the audience (Kara-Murza, 2018: 123). Metaphors of economic discourse are not only involved in the representation of economic reality but serve as a means of political propaganda and imposing certain stereotypes on mass consciousness (Karabulatova, 2013; Ryazantsev, 2015).

Focusing on the author planned perception of real events is achieved by including in the context the precedent texts with a high degree of suggestive influence. So-called "commonplaces" (folklore, the sacred and canonical texts) form the "basic concepts of morality" (Rozhdestvenskij, 2003). ${ }^{2}$ Objective reality is reviewed and assessed in the light of the eternal. Thus, analysts predict that the "departure" of Greece from the monetary union will open a sort of "Pandora's box", for Greece, followed by other countries: "And with chaos all around them, the Greek government says Prime Minister Alexis Tsipras has agreed to present a proposal to Germany's Angela Merkel and on

\footnotetext{
${ }^{2}$ Retrieved on 01 January 2019 from, http://evartist.narod.ru/text7/36.htm

${ }^{3}$ Retrieved on 01 January 2019 from, https://dailytimes.com.pk/101551/greece-and-theeuropean-union/
}

Tuesday. So perhaps Prime Minister Tsipras shares in the people's hope - and that hope remain firmly inside a Pandora's Box" (Seth, 2015)..$^{3}$

Economic metaphors illustrate the search for solutions to problems arising in the value system of society. As we can see from the examples, economic metaphors are directly related to the concept of valuation (Musolff, 2006). Evaluation occurs at the emotional level as a result of the formation of primary human needs, which occurs in childhood, and then operates at the level of consciousness, formed at a later age based on cultural and social experience (Ritchie, 2004).

\section{Conclusion}

The study aimed at critically analysing the use of stable expressions in modern economic discourse as an emotional increase in the potential impact on purchasing power. Direct impact on the public opinion formation is also applied by the author's own rhetorical "decoding" of metaphors, revealing its importance and orientation (Vyhrystyuk et al., 2017). We can say that metaphors of economic discourse, not only have validity aspects, they also bear the imprint of the social environment in which they once originated (Zelenskaya et al., 2018). With their help, the audience is guided to the actual perception of reality.

Combination of various metaphorical models in the same context creates more vivid images and doubles the axiological effect. So the given metaphorical context presents the combination of mechanical, anthropocentric and transport metaphors: "With the Eurozone economy stuck in a rut, despite European Central Bank efforts to pump money into the system, pressure is mounting for Germany to use its healthy budget position to increase public investment, stimulate demand and spur growth" (Taylor, 2014). ${ }^{4}$

\footnotetext{
${ }^{4}$ Retrieved on 01 January 2019 from, http://www.nytimes.com/2014/09/30/business/internati onal/germany-keeps-its-economic-engineidling.html?_r=1
} 
In another example, morbial and game metaphors allow the recipient on the basis of the usual associations realise the critical situation of the Greek economy which needs rehabilitation and even economic diet: "Greece's new government disagrees fundamentally with the troika's prescription of putting Greece on an economic diet to restore its 'health' ... The US and EU financial architecture [were] like a pyramid scheme where dodgy financial instruments of all sorts were circulating, creating an illusion of prosperity with very little transparency and a widely shared belief that the economic merry-go-round had acquired its own never-ending momentum. However, [...] unsurprisingly, the financial dominoes started to fall in the US and Europe" (Taylor, 2014). ${ }^{5}$ Colour semiotics actively correlates with the metaphorical term formation. White, grey or black colour indicates the legitimacy degree of economic activity. Let us compare:

- white knight-person or company that makes it desirable takeover bid;

- grey knight-opponent-contender in the "battle" for the taking of control of another company, whose intentions are not declared;

- black knight - the person or company making a company's unsolicited offer of its absorption;

- grey market - any market of scarce goods, which differs from the "black market" only in that it is legal;

- black-market - the illegal market of goods or services.

Certain parts of the body receive symbolic interpretation under the influence of the inner semiotics: brain trust - a group of highly qualified, deeply-minded professionals; brainstorming - effective mental method of solving the problem; Iron Arm - a symbol of somebody's mighty power.

Thus, imagery and evaluation play the role of meaning generation in English-language journalistic texts on economic topics. This feature is manifested in the specificity of the structure of the analytical article on the economic topic following the type of metaphorisation (Zelenskaya et al., 2018). At the same time, we must consider that the economic metaphor acts as a way of forming a confident evaluative attitude to the economic phenomenon, event and/or phenomenon described in the study.

\section{References}

Anderson, R.D. Jr. (2002). Anderson, R.D. Jr. The casual power of metaphor in politics. Retrieved on 14 April 2019 from, http://www.sscnet.ucla.edu/polisci/faculty /Anderson/MetaphorsCauses. html.

Bakhtin, B.M. (1975). Questions of literature and aesthetics. Moscow: Khudozhestvennaya Literatura, 504

Gavrilova, J. (2014). Systemic-functional approach in Michael Halliday Linguistics. Bulletin of the Moscow State regional university. Series: Linguistics. 3, 16-21. Retrieved on 10 August 2019 from: https://elibrary.ru/item.asp?id=21715742.

Financial Dictionary (2020). Retrieved on 4 January 2020 from, https://ru.mfginvest.com/zombie-bank.

Karabulatova, I.S. (2013). The problems of linguistic modeling of new Eurasian linguistic personality in multilinguistic and mental environment (by example of onomasphere). Middle-East Journal of Scientific Research, 17(6), 791-795. DOI:

10.5829/idosi.mejsr.2013.17.06.12262.

Karabulatova I., Vildanov Kh., Zinchenko A., Vasilishina E., Vassilenko A. (2017). Problems of transformation matrices modern multicultural identity of the person in the variability of the discourse of identity electronic Information Society. Pertanika. Journal of Social Science \& Humanities. 25(S). 1-16. Retrieved on 21 January 2020 from, https://elibrary.ru/item.asp?id=31061201

\footnotetext{
${ }^{5}$ Please refer to footenote 2
} 
Kara-Murza, S.G. (2018). Manipulations with consciousness. Moscow: Publishing House "Rodina", 432

Klanshhakova, A.Ju. (2003). The metaphor in the structure of economic discourse: experience of complex investigation (based on English language): Thesis for the degree of Candidate of Philological Sciences, Irkutsk, Irkutsk State University,181.

Khachmafova, Z. R., Karabulatova, I.S., Serebryakova, S.V., Zinkovskaya, A.V., Ermakova, E.N. (2017). The specifics of an estimate discourse of gender stereotypes in small forms of folklore in a network discourse of electronic and information society at the beginning of 21ct Century. Pertanika Journal of Social Science \& Humanities, 25 (S), 137-150.

Retrieved on 11 December 2019 from, https://elibrary.ru/item.asp?id=31063247/

Koryakovtseva, O. A., Doronina, I. I., Panchenko, T. M., Karabulatova, I. S., Abdullina, Z. M. (2016). Research of category "motivation" as a basic tool of personnel management. International Review of Management and Marketing. 6 (1S), 293-299. Retrieved on 24 January 2020 from, http://econjournals.com/index.php/irmm/articl e/view/1918/pdf

Kostruba, A. V. (2019). The rule of law and its impact on Socio-Economic, Environmental, Gender and Cultural Issues. Space and Culture, India, 7(2), 1-2. DOI:10.20896/saci.v7i2.522

Lakoff, G., Johnson, M. (2004). The metaphors we live by. Moscow: Editorial URSS, 35-42.

Luchinskaya E.N., Karabulatova I.S., Zelenskaya V.V., Golubtsov S.A. (2018). Characteristics of image of the Russian family in modern advertising discourse. Astra Salvensis, 6 (11), 699 -714. Retrieved on 16 December 2019 from, https://astrasalva.files.wordpress.com/2018/04 /as-supp-1.pdf

Mahnickaja, E.Ju. (2003). Metaphor in modern economic discourse and principles of lexicographic description. Dissertation. Rostovna-Donu.
Minsky M.L. (2006). The emotion machine: Commonsense thinking, artificial intelligence, and the future of the human mind. Simon and Schuster. Moscow: Publishing House "AST", 504.

Musolff, A. (2006). Metaphor scenarios in public discourse. Metaphor and Symbol, 1(21), 23-38. Retrieved on 16 April 2019 from, https://www.researchgate.net/publication/300 49898_Metaphor_Scenarios_in_Public_Discour se

Paris, R. (2004). Kosovo and the metaphor war. Political Science Quarterly, 117(3), 423-450.

Retrieved on 15 April 2019 from, http://aix1.uottawa.ca/ rparis/Metaphor.pdf

Riazi, A. (2003). The Invisible in translation: The role of text structure. Translation Journal, 7(2), Retrieved on 20 April 2019 from, https://www.translationjournal.net/journal/24s tructure.htm

Ritchie, L.D. (2004). Common ground in metaphor theory: Continuing the conversation. Metaphor and Symbol, 19(3), 233-244.DOI: 10.1207/s15327868ms1903_4

Rozhdestvenskij, Ju.V. (2003). Principles of modern rhetoric. Moscow: Flinta: Nauka. Retrieved on 26 January 2020 from, http://evartist.narod.ru/text7/36.htm

Ryazantsev, S.V., Karabulatova, I.S., Mashin, R.V., Pismennaya, E.E., Sivoplyasova, S.Yu. (2015). Actual problems of human trafficking in Illegal immigration in the Russian Federation. Mediterranean Journal of Social Science, 6(3), 621-626. DOI:10.5901/mjss.2015.v6n3s1. 621.

Saenko, N.R., Sozinova, A.A., Karabulatova, I.S., Akhmetov, I.V., Mamatelashvili, O.V., Pismennaya, E.E. (2016). Research in action integrated marketing communications as the elements of information and virtualization market relations. International Review of management and marketing, 6(1S), 267-272. Retrieved on 25 January 2020 from, http://econjournals.com/index.php/irmm/articl e/view/1914/pdf

Salter, L. (2003) Science and public discourse. History of intellectual culture, 3(1), 1-19. 
Retrieved on 16 January 2020 from, https://www.ucalgary.ca/hic/issues/vol3/2

Sanders, T.J.M., Spooren, W. (2012). Discourse and text structure. The Oxford Handbook of Cognitive Linguistics. Ed. by D.Geeraerts and H.Cuyckens. Retrieved on 28 December 2019 from, https://www.oxfordhandbooks.com/view/10.1 093/oxfordhb/9780199738632.001.0001/oxfor dhb-9780199738632.

Savchuk, I.P., Karabulatova I.S., Golubtsov S.A., Zelenskaya V.V., Akhmetova B. Z. (2019). Language features of the legend's genre as the basis of storytelling technology in advertising discourse. Amazonia Investiga, 8(21), 522 - 530. Retrieved on 6 January 2020 from, https://amazoniainvestiga.info/index.php/amaz onia/article/view/132

Seth, S.P. (2015). Greece and the European Union. Retrieved on 21 January 2020 from, http://www.dailytimes.com.pk/opinion/25-Feb2015/greece-and-the-european-union

Schmitt, R., Schröder, J., Pfaller, L. (2018). Metaphern und metaphorische Konzepte kognitive Linguistik nach Lakoff und Johnson. DOI: 10.1007/978-3-658-21460-9_1.

Shiganova, G.A., Karabulatova, I.S., Sviridova, A.V., Yuzdova, L. P. (2018) The concept of "knowledge" / "cognition" in Russian paremia: The Experience of structural semantic representation. Astra Salvensis, 6(12), 385-393. Retrieved on 25 December 2018 from, https://astrasalva.files.wordpress.com/2018/10 /astra-salvensis-vi-2018-no-123.pdf

Taylor P. (2014). Germany keeps Its economic engine idling. Retrieved on 11 May 2018 from, http://www.nytimes.com/2014/09/30/business /international/germany-keeps-its-economicengine-idling.html?_r=1

Temirgazina, Z., Akosheva, M., Yrysgul Sh., Shaharman A., Kurmanova Z., Kairova M. (2019). Metaphors in anatomical terminology. Space and Culture, India, 7(1), 143-153. DOI:10.20896/saci.v7i1.528

Vyhrystyuk M. S., Osipova, I. V., Karabulatova, I. S., Valentinovna, D. N., Druzhinina, O. M., Sabirova, S. G. (2017). Characteristics of gender stereotypes in modern advertising. Man in India, 97(23), 339-347. Retrieved on12 September 2018 from, https://elibrary.ru/item.asp?id=35489394 Wynne B. (2001). Creating public alienation: Expert cultures of risk and ethics on GMOs. Science as Culture, 10(4), 445-481. Retrieved on 10 April 2017 from, https://repository.library.georgetown.edu/hand le/10822/519561

Zelenskaya V.V., Golubtsov S.A., Karabulatova I. S., Kanon I. A., Kasyanova Z. S. (2018). Innovative discourse in the formation of a modern ethno-cultural environment. Astra Salvensis, 6(12), 753-766. Retrieved on 25 December 2018 from, https://astrasalva.files.wordpress.com/2018/10 /astra-salvensis-vi-2018-no-123.pdf

\section{Acknowledgements}

This study has been completed with the help of the financial support granted by the Ministry of Education and Science of the Russian Federation under the Program of Increasing the Competitiveness of PFUR "5-100" among the world's leading scientific and educational centres for 2016-2020.

\section{Disclosure Statement}

The authors declare no conflict of interests 